\section{Pyruvate Kinase Activity and Protein Concentration in 'd'Anjou' Pear Fruit with Cork Spot}

\author{
Robert Bevacqua ${ }^{1}$, Eugene Mielke, Timothy Facteau, Ruth Lavon', \\ and Paul Chen \\ Mid-Columbia Agricultural Research and Extension Center, 3005 \\ Experiment Station Drive, Hood River, OR 97031
}

Additional index words. Pyrus communis, biochemistry, postharvest physiology, disorder, nutrition, calcium

\begin{abstract}
An assay for pyruvate kinase (PK) was tested as a diagnostic tool for cork spot, a major physiological disorder in pear Pyrus communis L. cv. d'Anjou) fruit. $P K$ activity and $C a$ and protein concentrations were measured in peel of normal and affected fruit during selected months in 2 years. Protein concentration was more closely associated with cork spot than PK activity or Ca concentration. These preliminary results suggested the $\mathrm{PK}$ assay was a poor diagnostic tool for cork spot.
\end{abstract}

Cork spot is one of the major disorders in 'd'Anjou' pear fruit in the United States. It is assumed to be similar to bitter pit in apple and blossom-end rot in tomato and watermelon (Shear, 1975). Cork spot is generally linked with low $\mathrm{Ca}$ concentration in the fruit (Mason and Welsh, 1970; Raese, 1986, 1988; Richardson and Al-Ani, 1982; Richardson and Lombard, 1979; Woodbridge, 1971). Although $\mathrm{Ca}$ is the mineral element most often related to this fruit disorder, the results of fruit $\mathrm{Ca}$ analysis can sometimes vary widely and, therefore, cannot be used reliably to diagnose the problem (Bevacqua, 1989; Kupferman, 1988; Raese, 1986). The lack of a reliable analytical technique led to a search for an alternative method of identifying cork spot. The present study evaluated the feasibility of assaying pyruvate kinase (EC 2.7.1.40; PK) activity as a diagnostic tool. PK activity, Ca concentration, and protein concentration were compared to see which measurement was most closely associated with cork spot and, thus, might possess the greater value as a diagnostic tool for the disorder.

The use of a PK assay as an indicator for Ca-related disorders in fruit crops was proposed by Bar-Akiva et al. (1976). Calcium is an inhibitor of PK activity (Lavon et al., 1988a, 1988b; Tomlinson and Turner, 1973) and Bar-Akiva et al. (1976) showed that Ca

Received for publication 26 Mar. 1990. Oregon Agricultural Experiment Station Technical Paper no. 9197. This work was supported by a Binational U.S.- Israel Agricultural Research and Development (BARD) grant for the study of disorders of fruit. We thank Anita Miller, Tony Chen, and Jim Bagget, for their reviews of the manuscript. The cost of publishing this paper was defrayed in part by the payment of page charges. Under postal regulations, this paper therefore must be hereby marked advertisement solely to indicate this fact. ${ }^{1}$ Current address: South Coast Field Station, Univ. of California, 7601 Irvine Blvd.. Irvine, CA 92718 ${ }^{2}$ Dept. of Citriculture, The Volcani Center, Bet Dagan 50-250. Israel. deficiency in citrus caused an increase in PK activity.

Fruit samples were collected from six mature trees at the Mid-Columbia Agricultural Research and Extension Center (Table 1). Three of the trees were selected because of their histories of producing normal or marketable fruit. The other three trees were chosen because they had histories of producing fruit with a high incidence of the disorder. In 1988 and 1989, a tree prone to cork spar, designated $\mathrm{K} 6$, produced relatively normal harvests and was reclassified as a normal tree for those years (Table 1).

Samples designated as normal (N) were always prepared from fruit completely free of cork spot symptoms from trees with a low incidence of the disorder. Samples designated as cork spotted (CS) were prepared from fruit with obvious symptoms of cork spot that were from trees with a high incidence of the problem. An exception to this was the CS samples from May, June, July, and August of the 1988 crop year. Since cork spot symptoms emerged 21 days before harvest (7 Sept.) in 1988, the samples collected before that time possessed no outward symptoms and were simply fruit from trees that spot.

We selected six mature fruit or an equivalent mass of fruitlets from the same tree to form one sample. Fruit was collected from different heights and from all four sides of the tree. Fruit was stored at $-0.5( \pm 0.5)$ between harvest and analysis.

The fruit were rinsed with distilled water and wiped dry. The peel of the calyx half of the fruit was removed with a paring knife, chopped into $4.0-\mathrm{mm}^{2}$ pieces, and immediately covered with a cloth wetted with $0.5 \%$ (w/v) $\mathrm{Na}_{2} \mathrm{~S}_{2} \mathrm{O}_{5}$ solution to minimize oxidation. The tissue first was frozen at $-20 \mathrm{C}$ for $12 \mathrm{hr}$ and then freeze-dried for 6 days. Fresh and dry weights were recorded for each sample. The sample was rendered into powder and stored in plastic bags at - 20C. Sample collection was replicated three times.

Lyophilized tissue $(0.5 \mathrm{~g})$ was homogenized in a mortar and pestle with $0.5 \mathrm{~g}$ insoluble polyvinyl polypyrrolidone, $1.5 \mathrm{~g}$ white quartz sand, and $10.0 \mathrm{ml}$ of an extraction buffer that consisted of $50 \mathrm{~mm}$ imidazole$\mathrm{HCl}(\mathrm{pH}$ 7.0), $3 \mathrm{~mm}$ dithiothreitoi, $5 \mathrm{~mm}$ ascorbic acid, $3 \mathrm{mM} \mathrm{Na} \mathrm{S}_{2} \mathrm{O}_{5}, 14 \mathrm{mM}$ 2-mercaptoethanol, $1 \mathrm{mM}$ EDTA, and 20\% (v/v) glycerol. The macerated tissue was squeezed through two layers of Miracloth and centrifuged at $37,000 \times g$ for $20 \mathrm{~min}$ at $20 \mathrm{C}$. The supernatant was retained as the crude extract for the enzyme assay. The extraction procedure was performed at 20C.

PK activity was assayed by the colorimetric measurement of the pyruvate produced from phosphoenolpyruvate in the presence of adenosine - 5' - diphosphate (Bevacqua, 1989; Boyer, 1973; Lavon et al., 1988a, 1988b). The results were analyzed as specific activity (nmol pyruvateimin per milligram protein) or total activity (nmol pyruvate/min per gram dry weight or fresh weight).

The samples were analyzed for $\mathrm{Ca}$ concentration by an inductively coupled argon plasma apparatus. The 1988 postharvest samples were analyzed by atomic absorption spectrophotometer. Results were expressed as parts per million dry weight.

Soluble protein levels in the crude extract were assayed by Peterson's modification of the micro-Lowry method with precipitation
Table 1. Yield and incidence of cork spot at harvest for sample trees for 1987 through $1989^{z}$.

\begin{tabular}{|c|c|c|c|c|c|c|}
\hline \multirow[b]{2}{*}{ Criterion } & \multicolumn{6}{|c|}{ Tree designation } \\
\hline & E5 & F20 & $\mathrm{k} 13$ & K6 & P6 & P7 \\
\hline & \multicolumn{6}{|c|}{1987} \\
\hline Yicld (kg) & 227 & 293 & 259 & 20 & 56 & 58 \\
\hline Total fruit (no.) & 970 & 1320 & 1110 & 73 & 264 & 253 \\
\hline \multirow[t]{2}{*}{ Cork spot $(\%)$} & 1 & 1 & 2 & 36 & 23 & 24 \\
\hline & \multicolumn{6}{|c|}{1988} \\
\hline Yield (kg) & 270 & 117 & 161 & 171 & 294 & 150 \\
\hline Total fruit (no.) & 1317 & 456 & 627 & 687 & 1542 & 749 \\
\hline \multirow[t]{2}{*}{ Cork spol $(\%)$} & 1 & 5 & 4 & 7 & 15 & 23 \\
\hline & \multicolumn{6}{|c|}{1989} \\
\hline Yicld $(\mathrm{kg})$ & 215 & 157 & 170 & 160 & 167 & 99 \\
\hline Total fruit (no.) & 1157 & 781 & 925 & 814 & 1085 & 579 \\
\hline Cork spol $\left(\mathcal{F}_{c}\right)$ & 4 & 6 & 2 & 6 & 21 & 41 \\
\hline
\end{tabular}

'In 1987. trees E5, F20, and K13 were classified as normal (N) and trees K6, P6, and P7 were classified as prone to cork spot (CS). In 1988 and 1989, tree K6 produced relatively normal harvests and was reclassified as a normal tree for those years. 
Table 2. Total activity of pyruvate kinase (PK), and $\mathrm{Ca}$ and protein concentrations in 'd'Anjou' pear peel from normal (N) and cork spotted (CS) samples for selected months in 1987 and 1988.

\begin{tabular}{|c|c|c|c|c|c|c|c|}
\hline \multirow{2}{*}{$\begin{array}{c}\text { Crop } \\
y r\end{array}$} & \multirow{2}{*}{$\begin{array}{c}\text { Time } \\
\text { of } \\
\text { analysis } \\
\text { (month) }\end{array}$} & \multicolumn{2}{|c|}{$\begin{array}{l}\text { Total PK activity } \\
\text { (nmol pyruvatc/ } \\
\text { min per gram } \\
\text { dry wt x } 1000 \text { ) }\end{array}$} & \multicolumn{2}{|c|}{$\begin{array}{c}\text { Ca concn } \\
\text { (ppm dry wt) }\end{array}$} & \multicolumn{2}{|c|}{$\begin{array}{l}\text { Protein concn } \\
\left.\text { (mg. } \mathrm{g}^{-1} \text { dry } w t\right)\end{array}$} \\
\hline & & $N$ & CS & $N$ & $\mathrm{CS}$ & $N$ & $\mathrm{CS}$ \\
\hline 1987 & August & 0.18 & 0.55 & 416 & 347 & 4.69 & 5.92 \\
\hline 1987 & January & 0.45 & 0.42 & 648 & $491^{*}$ & 2.71 & 3.69 \\
\hline 1987 & February & 0.76 & 0.66 & 648 & 580 & 3.08 & 2.71 \\
\hline 1987 & May & 0.41 & 0.58 & na & na & 4.44 & 5.43 \\
\hline 1988 & May & 3.28 & 3.33 & $\$ 280$ & 5410 & 13.14 & 13.77 \\
\hline 1988 & June & 1.38 & $2.07^{\star}$ & 3510 & 4780 & 4.43 & $6.42^{*}$ \\
\hline 1988 & July & 1.00 & 1.39 & 1350 & 1470 & 3.33 & $5.68^{*}$ \\
\hline 1988 & August & 1.26 & 1.47 & 909 & 1010 & 4.46 & $5.97^{*} \bullet$ \\
\hline 1988 & Seplember & 1.23 & 1.04 & 565 & $850^{\circ}$ & 4.88 & $5.92 * \cdots$ \\
\hline 1988 & November & 2.34 & $2.62=$ & 1130 & 1530 & 5.54 & $8.82^{\circ}$ \\
\hline 1988 & December ${ }^{2}$ & 2.34 & 2.11 & 1430 & 1380 & 4.56 & $7.04 * *$ \\
\hline 1988 & January & 2.06 & 1.91 & 1300 & 1690 & 7.35 & 6.78 \\
\hline
\end{tabular}

${ }^{\mathrm{z}}$ Results for November, December, and January of 1988 crop year arc based on a comparison of fruit from two sample trees E5 and P7. whereas the earlier results arc based on a comparison of fruit from six sample trees (Table 1).

(Peterson, 1977). The results were analyzed as milligrams per milliliter, milligrams per gram dry weight, and milligrams per gram fresh weight.

Results were statistically analyzed separately for each month. Monthly means for $\mathrm{N}$ and CS samples were calculated from three to 12 measurements. A $t$ test (Sokal and Rohlf, 1981) was used to test for significant differences between the means for $\mathrm{N}$ and CS samples in a given month.

Total PK activity was measurably different between $\mathrm{N}$ and CS fruit in June and November of the 1988 cropping season, but not in any of the other 10 months in which the assays were performed (Table 2). These results were the same whether total activity was expressed on a dry- or fresh-weight basis. Specific activity was eliminated as a diagnostic measure for cork spot because the relationship between $\mathrm{N}$ and CS fruit reversed from the 1988 harvest (August) to the 1989 harvest (September). Thus, PK activity, regardless of the units of measurement, appears a poor candidate for diagnosing cork spot.

Calcium concentration was lower in CS fruit than in N fruit in January of the 1987 crop year. However, $\mathrm{Ca}$ concentration was higher in CS fruit than in N fruit in September of the 1988 crop year (Table 2). These variable results and the inability to detect measurable differences in the other months of the 1987 and 1988 crop years clearly illustrate the weakness of using $\mathrm{Ca}$ analysis to diagnose cork spot.

Protein concentration $\left(\mathrm{mg} \cdot \mathrm{g}^{-1}\right.$ dry weight) provided the greatest measurable difference between $\mathrm{N}$ and $\mathrm{CS}$ fruit for the most months in the 1987 and 1988 crop years. There were strong positive correlations between the re- sults based on the above unit and those based on milligrams per milliliter $(r=0.91)$ milligrams per gram fresh weight $(r=0.94)$, indicating that regardless of the units of measurement, the assay for protein concentration yielded similar results. Protein concentration was higher in disordered fruit than in $\mathrm{N}$ fruit in June through September and in November and December of the 1988 crop year (Table 2). Protein concentration expressed as milligrams per milliliter was also higher in affected fruit than in $\mathrm{N}$ fruit in Aug. 1987.

The specific activity of an enzyme is expressed on a protein basis. It was for this reason that protein concentration was assayed in each sample. This led to the unexpected but important finding that CS fruit generally contained higher protein concentrations than $N$ fruit. It was a pattern generally free of the wide variability, reversals, or lack of measurable differences often associated with fruit $\mathrm{Ca}$ analysis or the $\mathrm{PK}$ assays. High protein content has also been reported for apple fruit with bitter pit and other Ca-related disorders, such as internal breakdown (Faust and Shear, 1968, 1969). The symptoms of cork spot first became apparent in our sample trees 21 days before harvest in the 1988 crop year. Yet, the protein assay detected differences between fruit from normal trees and fruit from trees prone to cork spot as early as June, i.e., 3 months before harvest (Table 2). Faust and Shear (1968) reported that apple tissue with corking disorders had higher protein content than normal tissue and that the increase had occurred by the time the first visible signs of the disorder developed. The present results, although based on few trees, and the earlier ones indicate that the assay for protein concentration merits further study for its poten- tial to diagnose or predict cork spot early in the growing season.

\section{Literature Cited}

Bar-Akiva, A., J. Sagiv, and D. Hasdai. 1976. Effect of mineral nutrient deficiencies on pyruvic kinase activity in citrus leaves. Proc. IV Intl. Colloq. Control of Plant Nutr. 1:109-118.

Bevacqua, R.F. 1989: Mineral nutrition, pyruvate kinase activity, and protein concentration in 'd'Anjou' pear fruit with cork spor. PhD Diss., Oregon Stare Univ., Corvallis.

Boycr, P.D. 1973. Pyruvate kinase. Annu. Rev. Plant Physiol. 24:95-113.

Faust. M. and C.B. Shear. 1968. Corking disorders of apples: a physiological and biochemical review. Bor. Rev. 34:341-469.

Faust, M. and C.B. Shear, 1969. Biochemical changes during the development of cork spot of apples. Qual. Plant. Mater. Veg. XIX, 1-3:255265.

Kupferman, E. 1988. Fruit mineral analysis-an update. Post-harvest Pomol. Nwsl. Washington State Univ. 6(2):3-7.

Lavon, R.. R. Salomon, and E. Goldschmidt. 1988a. Pyruvate kinase: a potential indicator of calcium level in citrus leaves and fruit, p. 541545. In: R. Goren and K. Mendel (eds.). Proc. 6th Intl. Citrus Congr. Tel Aviv. Israel.

Lavon, R., R. Salomon, and E. Goldschmidt. 1988b. Pyruvate kinase activity of citrus leaves as affected by $\mathrm{K}^{+}, \mathrm{Mg}^{+2}$, and $\mathrm{Ca}^{+2}$ deficiencies. Contr. Agr. Res. Org., The Volcani Center. Israel, no. 2270-E.

Mason. J.L. and M.F. Welsh. 1970. Cork spot (pit) of 'Anjou' pear related to calcium concentration in fruit. HortSciencc 5(5):447.

Peterson, G.L. 1977. A simplification of the protein assay method of Lowry et al. which is more generally applicable. Anal. Biochem. 83:346 356.

Raese, J.T. 1986. Nitrogen and calcium important in determining yield, fruit quality, and disorders of 'Anjou' pears. Proc. 1986 Pacific Northwest Tree Fruit Shortcourse. p. 156-168.

Raese, J.T. 1988. Calcium sprays and fertilizers found effective against 'd'Anjou' pear disorders. The Good Fruit Grower 39(17):35-39.

Richardson, D.G. and A.M. Al-Ani. 1982. Cork spot of 'd'Anjou' pear fruit relative to critical calcium concentration and other minerals. Acta Hort. 124:113-118.

Richardson, D.G. and P.B. Lombard. 1979. Cork spot of 'Anjou' pear: control by calcium sprays. Commun. Soil Sci. \& Plant Anal. 10(1\&2):383389.

Shear, C.B. 1975. Calcium-related disorders of fruits and vegetables. HortScicncc 10(4):361365 .

Sokal, R.R. and F.J. Rohlf. 1981. Biometry: the principles and practice of statistics in biological research. Freeman, San Francisco.

Tomlinson, J.D. and J.F. Turner. 1973. Pyruvatc kinase of higher plants. Biochimica et Biophysica Acta 329:128-139.

Woodbridge, C.G. 1971. Calcium level of pear tissues affected with cork and black end. HortScience 6(5):451-453. 